\title{
PREVALÊNCIA DE BRUCELOSE BOVINA NA REGIÃO NOROESTE DO ESTADO DO PARANÁ DE 2014 Á 2016
}

\author{
Ricardo Magalhães ${ }^{1}$ \\ Gilnéia da Rosa ${ }^{2}$ \\ Jady Slaviero Tieppo ${ }^{3}$ \\ Lahis Cristina Basso ${ }^{4}$ \\ Maria Leticia da Silveira Ames ${ }^{5}$ \\ Luiz Sérgio Merlini ${ }^{6}$
}

MAGALHÃES, R.; ROSA, G.;TIEPPO, J. S.; BASSO, L.C.; AMES, M. L. da S.; MERLINI, L. S. Prevalência de brucelose bovina na região noroeste do estado do Paraná de 2014 á 2016. Arq. Ciênc. Vet. Zool. UNIPAR, Umuarama, v. 21, n. 4, Anais do II Concivet 2018, p. 149-150, out./dez. 2018.

RESUMO: Dentre as zoonoses responsáveis pelas maiores perdas socioeconômicas na bovinocultura brasileira, a brucelose possui significativo destaque, sendo considerada uma antropozoonose causada pelas bactérias do gênero Brucella spp. Essas bactérias possuem potencial para infectar diversos mamíferos, inclusive, existem registros de brucelose em cetáceos (baleias e golfinhos). Nos bovinos, as principais maneiras de transmissão se dão pelas descargas bacterianas presentes nos restos de materiais provenientes de abortos de vacas positivas para brucelose, mas também pode ser transmitida pelo leite, cópula, fômites, solo e até a água. As vacas continuam liberando as bactérias por cerca de 30 dias após o parto ou aborto. Para diagnóstico são utilizados testes diretos ou indiretos preconizados pelo Programa Nacional de Controle e Erradicação da Brucelose e da Tuberculose Animal (PNCEBT). O objetivo deste trabalho foi avaliar o perfil epidemiológico de Brucelose bovina na região noroeste do estado do Paraná de 2014 a 2016. Entre os anos de 2014 a 2016, foram utilizados dados de exames realizados por Médico Veterinário devidamente registrado e habilitado para a realização do diagnóstico. Entre bovinos machos e fêmeas foram testados 12.640 animais, na região noroeste do estado Paraná, sendo o teste utilizado o do antígeno acidificado tamponado (AAT). 26 animais foram positivos para brucelose, perfazendo um percentual de $0,2 \%$ do rebanho analisado. Apesar dos baixos índices de animais infectados pela Brucella spp. apresentados nessa pesquisa o controle e uma possível erradicação da brucelose se tornam indispensáveis devido à fácil transmissão e às perdas econômicas provocadas, principalmente pelos abortos ocorridos nos últimos trimestres das gestações.

PALAVRAS-CHAVE: Bovino. Brucella spp. Epidemiologia. Zoonose.

\section{BOVINE BRUCELLOSIS PREVALENCE IN THE NORTHWEST REGION OF THE STATE OF PARANÁ FROM 2014 TO 2016}

\begin{abstract}
Brucellosis features among the zoonoses responsible for greatest socioeconomic losses in the Brazilian cattle farming. Considered an anthropozoonosis, its etiological agents are bacteria of the Brucella spp genus. Such bacteria have the potential to infect several mammals, with records of brucellosis even in cetaceans (whales and dolphins). In cattle, it is mainly transmitted through bacterial discharges present in the remains of materials coming from abortions tested positive for brucellosis. Nevertheless, it can also be transmitted by milk, copulation, blood transfusions, fomites, soil and even water. Cows continue releasing the bacteria for about 30 days after calving or abortion. Direct or indirect tests as recommended by the National Program for the Control and Eradication of Brucellosis and Animal Tuberculosis (PNCEBT) can be used for diagnosis. The objective of this study was to assess the epidemiological profile of bovine brucellosis in the northwestern region of the State of Paraná from 2014 to 2016. Between 2014 and 2016, data from examinations performed by a veterinarian duly registered and qualified to perform the diagnosis were used. A total of 12,640 animals in the northwest region of the state of Paraná were tested, both male and female, using the acidified buffered antigen (ABA). A total of 26 animals tested positive for brucellosis, which corresponds to $0.2 \%$ of the studied herd. Despite the low rates of animals infected with Brucella spp. presented in this study, the control and possible eradication of brucellosis is essential due to its easy transmission and extensive economic losses mainly caused by abortions occurring during the last quarters of pregnancies.
\end{abstract}

KEYWORDS: Bovine. Brucella spp. Epidemiology. Zoonosis.

\footnotetext{
DOI: 10.25110 /arqvet.v21i4.2018.7344

'Acadêmico do curso de Medicina Veterinária da Universidade Paranaense (UNIPAR), Campus II, Rodovia PR 480, Km 14, Parque Bonfim, CEP. 87.502970, Umuarama - PR, Brasil. E-mail. ricardomagalhaesvet@gmail.com

${ }^{2}$ Acadêmica do curso de Medicina Veterinária da Universidade Paranaense (UNIPAR), Campus II, Rodovia PR 480, Km 14, Parque Bonfim, CEP. 87.502970, Umuarama - PR, Brasil. E-mail. jst_tieppo@hotmail.com

${ }^{3}$ Mestrandra Universidade Estadual de Santa Catarina - UDESC, Folorianópolis - SC. E-mail: gilneia.medvet@gmail.com

${ }^{4}$ Biomédica - Universidade Paranaense - UNIPAR), Campus II, Rodovia PR 480, Km 14, Parque Bonfim, CEP. 87.502-970, Umuarama - PR, Brasil

${ }^{5}$ Acadêmica do curso de Medicina Veterinária da Universidade Paranaense (UNIPAR), Campus II, Rodovia PR 480, Km 14, Parque Bonfim, CEP. 87.502-

970, Umuarama - PR, Brasil. E-mail. maria.leticia.ames@gmail.com

${ }^{6}$ Docente do curso de Medicina Veterinária da Universidade Paranaense (UNIPAR), Campus II, Rodovia PR 480, Km 14, Parque Bonfim, CEP. 87.502-970, Umuarama - PR, Brasil. E-mail.merlini@unipar.br
} 


\section{PREVALENCIA DE BRUCELOSIS BOVINA EN LA REGIÓN NOROESTE DEL ESTADO DE PARANÁ DE 2014}

\section{A 2016}

RESUMEN: Entre las zoonosis responsables por las mayores pérdidas socioeconómicas en la bovinocultura brasileña, la brucelosis posee significativo destaque, es considerada una antropozoonosis causada por bacterias del género Brucella spp. Esas bacterias poseen potencial para infectar diversos mamíferos, incluso, existen registros de brucelosis en cetáceos (ballenas y delfines). En los bovinos, las principales formas de transmisión se dan por las descargas bacterianas presentes en los restos de materiales provenientes de abortos de vacas positivas para brucelosis, también puede ser transmitida por la leche, cópula, fómites, suelo e incluso el agua. Las vacas continúan liberando las bacterias durante unos 30 días después del parto o aborto. Para el diagnóstico se utilizan pruebas directas o indirectas preconizadas por el Programa Nacional de Control y Erradicación de Brucelosis y de la Tuberculosis Animal (PNCEBT). El objetivo de esta investigación ha sido evaluar el perfil epidemiológico de Brucelosis bovina en la región noroeste del estado de Paraná de 2014 a 2016. Entre los años de 2014 a 2016 se utilizaron datos de exámenes realizados por Médico Veterinario debidamente registrado y habilitado para la realización del diagnóstico. Entre bovinos machos y hembras se probaron 12.640 animales, en la región noroeste del estado de Paraná, la prueba utilizada fue antígeno acidificado tamponado (AAT). 26 animales atestaron positivos para brucelosis, lo que significó el 0,2\% del rebaño analizado. A pesar de los bajos índices de animales infectados por Brucella spp. presentados en esa investigación, el control y una posible erradicación de la brucelosis se vuelven indispensables debido a su fácil transmisión y las pérdidas económicas provocadas, principalmente por los abortos ocurridos en los últimos trimestres de las gestaciones.

PALABRAS CLAVE: Bovino. Brucella spp. Epidemiología. Zoonosis. 